Reviews

\title{
Living Under Contract. Edited by Peter D. Little and Michael J. Watts. Madison: University of Wisconsin Press (1994). xviii, 298 pp.
}

\section{Reviewed by John Magistro, National Center for Atmospheric Research.}

Living Under Contract is a meticulously crafted compilation of comparative case studies on contract farming carried out from 1986 to 1988 in seven sub-Saharan countries under the auspices of the Institute for Development Anthropology. The editors have embarked on an ambitious journey, tackling the broad theoretical and empirical parameters under which highly amorphous and heterogeneous forms of the contracting process have emerged in recent times. In this sense, capturing the wide permutations and contours of a reconfigured agro-industrial food sector in Africa, the editors and contributors to this compendium have successfully accomplished their mission.

The strength of this edited volume lies in the parity and complementarity of development narratives that so skillfully merge theory with praxis. The editors are highly adept in providing the theoretical backdrop, mapping out the historical, social, political, and economic topography of the contracting process, while each authored case study casts light on the broad configurations under which the contracting arrangement takes its variegated form and function.

This volume is a study, writ large, of the reconfiguration and industrialization of the agrarian sector in sub-Saharan Africa over the past several decades, of which contract farming has become a central defining feature of the landscape. The editors are explicit in stating their theoretical affiliation from the outset in the introductory chapter, positing a neo-Marxian reading of the contracting script as "a form of industrial appropriation of discrete activities within the agrarian production process" (p.6). The introduction, by Little and Watts, followed by Watts" chapter entitled "Life under Contract," very nicely sketch out the thematic contours, historical trajectories, and interpretive theoretical frames that lie at the boundaries of the contracting process. Little and Watts set the stage by briefly situating the contract in its historical context, identifying its early forebears in the United States, Europe, and colonial Africa dating back to the 1930s and 1940s. They adopt an extended, albeit precise definition of contracting as:

forms of vertical coordination between growers and buyers-processors that directly shape production decisions through contractually specifying market obligations (by volume, value, quality, and, at times, advanced price determination); provide specific inputs; and exercise some control at the point of production (i.e., a division of management functions between contractor and contractee) (p. 9).

The editors are quick to point out that sound empirical studies of contract farming in Africa, grounded in field-based microeconomic data, have been quite sparse. Previous attempts at delineation of contracting have focused on "technological or commodity-based approaches," neglecting the political, historical, and social contexts that are critical in shaping the contractual process. Thus, the value-added contribution of this volume is the situationally specific, contextual locus of the contract, embedded within a larger political and historical economy. It is the complex web of intersecting political, historical, and social forces, rather than the technological attributes of the commodity per se ö according to the authors - that drives the overall performance and outcome of the contracting arrangement.

Little and Watts identify four major unifying themes that underlie the range of case studies presented in this book: the saliency of historical and politico-economic contexts, the collusion of interests and institutional linkages between state and private capital, the primacy of labor dynamics and production relations, and the undercurrents of grower politics and strategies. They 


\section{Reviews}

site historical examples of colonial British experiments with contract production in Kenya and Zimbabwe to illustrate how historical and politico-economic forces can predetermine certain structural features of the contracting process operating at present. The importance of time-series analysis and historical depth in capturing the oscillation and volatility of international commodity markets is underscored in a number of the case studies. They also illuminate the ubiquitous presence of the state in supposedly dichotomous spheres of public-private control, and the extent to which state intervention, discreet or otherwise, often imposes its will in the market arena in the form of regulatory pricing, and preferential contracting and infrastructural services to private firms. Thus, an IMF/World Bank neo-liberal ideology of unfettered markets masks the reality of state monopsony that is alive and well in the agribusiness-contracting industry.

Key findings concerning the internal configurations of household labor dynamics from these case studies suggest that contract production is highly labor-intensive, that heavy labor burdens are assumed disproportionately by women and children, and that returns per unit of labor are low in relation to off-farm wage earning strategies. Little and Watts conclude that in general, the case studies are persuasive in suggesting that contract production subjugates and constrains labor, rather than liberating it. Finally, with respect to peasant-management labor relations under contract, discreet forms of peasant subversion of the contract, not altogether unlike Scott's notion of peasant resistance (1985), are manifest in several case studies, whereby labor is totally (Carney, Ch. 5) or partially (Little, Ch. 7) withdrawn from production as a form of protest against scheme management.

Watts sets the stage for a detailed exploration of the situationality of each case study by locating the contract within the broader canvas of a continuously permuting political economy. Historical parallels are drawn between contracting in the US and Europe earlier this century, and the current constellation of contracting forms that are surfacing in Africa and the developing world in general. Watts contests neoclassical economic analyses of contracting as a purely technical arrangement. Rather, he places contracting within a neo-Marxist framework in which social relations of production and control of the labor process become the central defining features. His characterization of the contract as subsumed within a broader phenomenon of global restructuring of agrarian production relations is perhaps best captured as follows:

contracting signifies both the advance of the industrial appropriation of rural production processes.the shift from agricultural production to agro-industrial productionand of the social integration of agriculture associated with transnationalization (p. 24).

In adopting this position, he periodically references Harriet Friedmann's and Phil McMichael's critical work on "agro-food restructuring" in order to buttress his position. Using their work as an historical baseline, he summarizes the historical trajectory and internationalization of food production regimes, of which Africa has become a more recent convert.

Watts covers broad ground, assessing the various social configurations of production organization from state-owned nucleus-estate schemes to less centralized joint ventures of local and foreign capital firms supplied by smallhold outgrowers. Both he and Little concur that contracting schemes in general appear to favor more capitalized smallholders, largely neglecting the poorest segments of the population. Economic differentiation is pronounced among outgrowers, particularly with the emergence of a nascent class of absentee landowners who benefit economically from the marginalized labor of poorer peasants. Watts" overall assessment of the subordination of labor and the "capture" of a peasantry under contract farming is best encapsulated in the following statement:

Nominally independent growers retain the illusion of autonomy but have become in practice what Lenin called propertied proletariansGrowers take on the character of a glorified selfemployed proletariat (p. 64).

Watts further develops his analysis of labor marginalization by portraying the smallhold

$142 \quad$ Vol. 61999

Journal of Political Ecology 
Reviews

contracting arrangement as a reconstituted form of the self-exploited Chayanovian peasantry. This form of "appropriationism" (see Goodman, Sorj, and Wilkinson 1987; more fully developed in Watts" closing epilogue), and the disciplining of labor through contractual relations, periodically ignites gendered divisions of internal dissent and tension within the conjugal household, as in the case of increased women's labor burdens in rice irrigation in the Gambia (see Carney, Ch. 5). Watts concludes his chapter by situating the contract within the larger frame of flexible accumulation of capital in the twentieth century. He illustrates the structural parallels between industrial and agricultural contracting, in which labor outsourcing lowers production costs and economic risk to agro and industrial technology, a hallmark of flexible accumulation in an emerging era of global economic integration.

Watts" argument for "disguised proletarianization" is elaborated empirically in Roger Clapp's chapter entitled "The Moral Economy of the Contract." Clapp refers to "the politics of representation" in describing the illusory nature of autonomy as stipulated within the contract as a form of "disguised proletarianization." Using examples from Latin America instead of Africa (a banana cooperative in Honduras and contract barley production in Peru), he demonstrates that contractual relations are not reciprocal obligations of equity between grower and buyer-processor, but rather social relations of unequal exchange that are obscured by juridical forms of representation weighted in favor of the latter.

The empirical case studies used as supporting evidence for the theoretical conclusions drawn by Little and Watts include: Steven Jaffe's historical review of the myriad of horticultural contracting schemes proliferating in Kenya since World War II (Ch. 3); Jackson and Cheater's treatment of a broad spectrum of contracting arrangements in the sugar, tea, and cotton sub-sectors of Zimbabwe, from state monopsony of grain marketing boards to private agribusiness marketing channels (Ch. 4); Carney's depiction of women's labor appropriation by the Jahaly-Pacharr rice irrigation project in the Gambia, in which the inequitable restructuring of conjugal relations within households prompts a form of proletarianized dissent among women farmers (Ch. 5);

Daddieh's rendering of the contrasting development trajectories of Cote d'Ivoire and Ghana in initiating oil palm production since independence in 1960 (Ch. 6); and Peter Little's balanced theoretical and empirical appraisal of a three-year comparative study of contract farming in Africa, including a diachronic analysis of the Perkerra Irrigation Scheme in Kenya dating back to the 1950s (Ch. 7).

Several of these chapters, while at times laboriously rooted in historical and economic specificity, nonetheless, point to the broad array of contracting forms and the multiplicity of intersecting forces of history, society, ecology, economy, and political institutions that challenge any attempt at simplistic theoretical explication. At times, the empirical presentation of evidence slows the reader in a quagmire of facts and data. However, it is precisely the historical and economic specificity of these chapters that is necessary in order to tease out the conjunction of so many complex interacting social and techno-biological variables.

Peter Little's concluding chapter, "Contract Farming and the Development Question," relates contracting to the broader themes of rural development and underdevelopment. He draws attention to the need for a broader assessment of contracting, that captures both on and off-farm impacts and more diffuse cross-sectoral dynamics within a larger regional context. He arrives at several conclusions: first, that what happens on the farm under contract, may or may not be positive off the farm, and may have ancillary effects on a broad range of actors beyond the immediate purview of the contract. Second, contracting must be understood as only one component within a broader array of diversified livelihoods and production activities that significantly shape strategies of labor deployment, risk aversion, household food security, and income generation and expenditure. Finally, he identifies the structural configurations of power relations in the contracting arrangement as the critical locus of analysis, concluding that "not all contracting schemes involve a transnational firm, a state-owned company, or a highly unequal power relationship" (p. 218). Drawing from his comparative data and that of horticultural production on the Perkerra 


\section{Reviews}

Scheme in Kenya, he illustrates the adverse impacts of contracting as it increases social differentiation and capital accumulation, alienates land and labor, heightens food insecurity, and displaces pastoral populations in the region.

This work closes with Michael Watts' synthetic theoretical contribution, situating the contract within the larger landscape of capitalist transformation in the twentieth century. He employs the term "appropriationsim" from Goodman, Sorj, and Wilkinson (1987), of which contracting functions as a surrogate, to mean "the discontinuous but persistent undermining of discrete practices within the agricultural process as they are industrialized and subsequently reincorporated into production" (p. 249). Within the broader parameters of a post-Fordist analysis, Watts tackles the theoretical dimensions of mass versus product differentiation, forms of "flexible integration" of production factors, and the vertical decomposition of capitalism into "subcontracting networks." He makes reference to a "new social economy" in the contracting arena, which implies a disciplining of the labor force under contract through various forms of social control, or what Burawoy (1985) terms "despotic and hegemonic production politics." He concludes: "Contracting is, however, part and parcel of appropriationism in the late twentieth century and of the complex ways in which industrialization advances within different commodity systems" (p. 256).

In conclusion, Little and Watts have ambitiously and successfully problematized one of the more complex and diffuse agrarian creatures now rearing it's multiple heads as we approach a new millenium ö the many and varied colors of the contract. The editors' ability to theoretize the contract, and the depth of the empirical archive of the other contributors, makes for an impressive and balanced reading of theory and practice in the many permutations of the contract. Coupled with McMichaels, Friedmann, and others contributing to the growing body of literature on global agro-food restructuring, this edition makes for an informative, instructive "must read" for use in the classroom syllabus.

\section{References Cited:}

Burawoy, Michael.

1985. The Politics of Production: Factory Regimes Under Capitalism and Socialism. London: Verso.

Goodman, David, Bernardo Sorj, and John Wilkinson.

1987. From Farming to Biotechnology: A Theory of Agro-industrial Development. Oxford: Blackwell.

Scott, James.

1985. Weapons of the Weak: Everyday Forms of Peasant Resistance. New Haven: Yale University Press.

$144 \quad$ Vol. 61999

Journal of Political Ecology 